Article

\title{
Geospatial Data Analysis and Economic Evaluation of Companies for Sustainable Business Development-An Interdisciplinary Teaching Approach
}

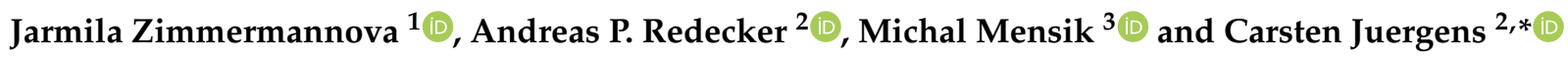 \\ 1 Department of Sustainable Development, Moravian Business College Olomouc, 77900 Olomouc, \\ Czech Republic; Jarmila.Zimmermannova@mvso.cz \\ 2 Geomatics Group, Institute of Geography, Faculty of Geosciences, Ruhr University Bochum, D-44870 Bochum, \\ Germany; andreas.redecker@rub.de \\ 3 Department of Economy and Management, Moravian Business College Olomouc, 77900 Olomouc, \\ Czech Republic; Michal.Mensik@mvso.cz \\ * Correspondence: carsten.juergens@rub.de
}

check for updates

Citation: Zimmermannova, J.; Redecker, A.P.; Mensik, M.; Juergens, C. Geospatial Data Analysis and Economic Evaluation of Companies for Sustainable Business Development-An Interdisciplinary Teaching Approach. Sustainability 2021, 13, 11245. https://doi.org/ $10.3390 /$ su132011245

Academic Editor: Elena Cristina Rada

Received: 4 September 2021

Accepted: 6 October 2021

Published: 12 October 2021

Publisher's Note: MDPI stays neutral with regard to jurisdictional claims in published maps and institutional affiliations.

Copyright: (c) 2021 by the authors. Licensee MDPI, Basel, Switzerland. This article is an open access article distributed under the terms and conditions of the Creative Commons Attribution (CC BY) license (https:// creativecommons.org/licenses/by/ $4.0 /)$.

\begin{abstract}
Sustainable business development is connected with environmental impact, natural resources and people. This makes the location a crucial factor for the operation of a business. Therefore, a combination of both geo-spatial data analysis and traditional economic evaluation of companies are advantageous. The consideration of geolocation is beneficial with calculations for process optimizations and cost efficiency as well as ecological and social compliance. Since integrating geospatial methods into economics is a rather new interdisciplinary approach, it seems necessary to establish innovative teaching concepts for the education of experts in this field. Creating and testing such new teaching concepts based on playful learning is the idea behind the ERASMUS+ project SPATIONOMY ("Spatial exploration of economic data-methods of interdisciplinary analytics"). An interdisciplinary team of teachers educates an interdisciplinary assembled group of international students. Hence, the fields of economics/business informatics and geography/geomatics are represented by participants and staff. Based on initial lessons about basic knowledge in the connected subjects, the central elements of the teaching concept are case studies and a simulation game, each with interdisciplinary challenges. The principal aim of the project-to educate students to become specialists in spatial economics - could be achieved. This paper aims to present, evaluate and discuss the methodological approach as well as the results from the application of the simulation game. The results show that the gamification of education is worthy. Simulation game-based learning appears to be more playful and experiential compared to traditional teaching approaches. Further research in this area should focus on the students' engagement evaluation and attitude towards sustainable behaviour in their own business.
\end{abstract}

Keywords: geospatial data analysis; sustainable business development; interdisciplinary teaching; playful learning; simulation game; spatial economy; spationomy; game studies; gamification

\section{Introduction}

\subsection{Business and Sustainability}

Sustainably operating a business means accounting for more than just economic numbers. It opens the scope of management beyond the mechanisms of profit and also considers environmental and social effects [1]. These are not covered by economic figures completely. However, they will have repercussions on the economic performance of the business sooner or later. Therefore, in business and economics, the necessity for advanced multi-perspective decision-making tools is increasing [2]. Besides pure economic and financial considerations, social and environmental aspects also need to be considered.

Regarding environmental aspects, greenhouse gases are the key driver of global warming [3]. The amount of anthropogenic greenhouse gases in the atmosphere is the result 
of several synergistic effects [4]. On the one hand, it is the consequence of the behaviour of economic entities, mainly households and companies [5,6], which can be measured by general indicators such as gross domestic product (GDP), or by specific indicators, such as the household final consumption expenditure, investments of companies or consumption of fuels. On the other hand, national environmental regulations are enacted, and economic instruments are introduced to set incentives for reduced greenhouse gas emissions for environmental and climate protection purposes [7]. For instance, European Union (EU) countries use various economic instruments of environmental policy, such as environmental taxes, fees, charges, tradable permits, deposit-refund systems or subsidies [8].

Regarding the impacts of economic growth [9], the literature underlines that economic growth is connected with rapid urbanization, an increase in production and growing transport demand [5]. This not only boosts energy consumption that might step up global warming, it also implies a growing demand for resources. In addition to that, rising amounts of pollutants such as particles, toxic matter, noise, etc., might be a threat to the natural environment as well as to humans.

The need for clean and environmentally friendly production is increasing, especially in industrialized societies and countries. It is connected with social aspects because new sectors provide new job opportunities and help to decrease unemployment [10]. We can observe new trends in business and the economy, such as a circular economy and a bioeconomy. For example, the bioeconomy or biobased economy encompasses the production of biobased resources and their conversion into food, feed, bioenergy and biobased materials [11].

Moreover, the European Commission [12] adopted a new environmental policy concept, the so-called "European Green Deal". All Member States committed to turning the EU into the first climate neutral continent by 2050. To get there, they pledged to reduce emissions by at least $55 \%$ by 2030, compared to 1990 levels. This will create new opportunities for innovation, investment and jobs, such as markets for clean technologies and products, the electrification of the economy, the greater use of renewable energy and greater energy efficiency. The changes are expected in sectors such as energy, transport, engineering, construction and renovation, helping create sustainable, local and well-paid jobs across Europe. The whole framework of this policy concept, "The Fit for 55 package", is illustrated by Figure 1.

Concerning these new trends, the importance and the necessity of economic models in this area are increasing. In particular, it is the case for models representing suitable tools for decision making. However, the decision making of companies is connected with various aspects and variables, not only economic ones. Therefore, a multidisciplinary approach that evolves beyond a purely economic approach into a holistic business perspective, that also accounts for social and environmental interactions, is necessary.

Most economic data (e.g., factory locations, traffic networks, customers, etc.) have an inherent geo-spatial component [13]. Nowadays, this geo-spatial component of economic data sets becomes increasingly important and leads to spatial analysis in specific economic fields $[14,15]$. For the evaluation of economic resources, added value is achieved by applying geo-spatial data analysis methods [16-18]. For instance, customers have a certain spatial distribution or any renewable resource such as wind or irradiation of the sun appears at a certain location or area. Every physical and many virtual objects (and people also) are linked to space by geo-location (coordinates). Additionally, they possess attributes that are more or less dependent on their spatial manifestation. Analysing spatial relationships in conjunction with other known properties of certain entities can unveil crucial information about them. 


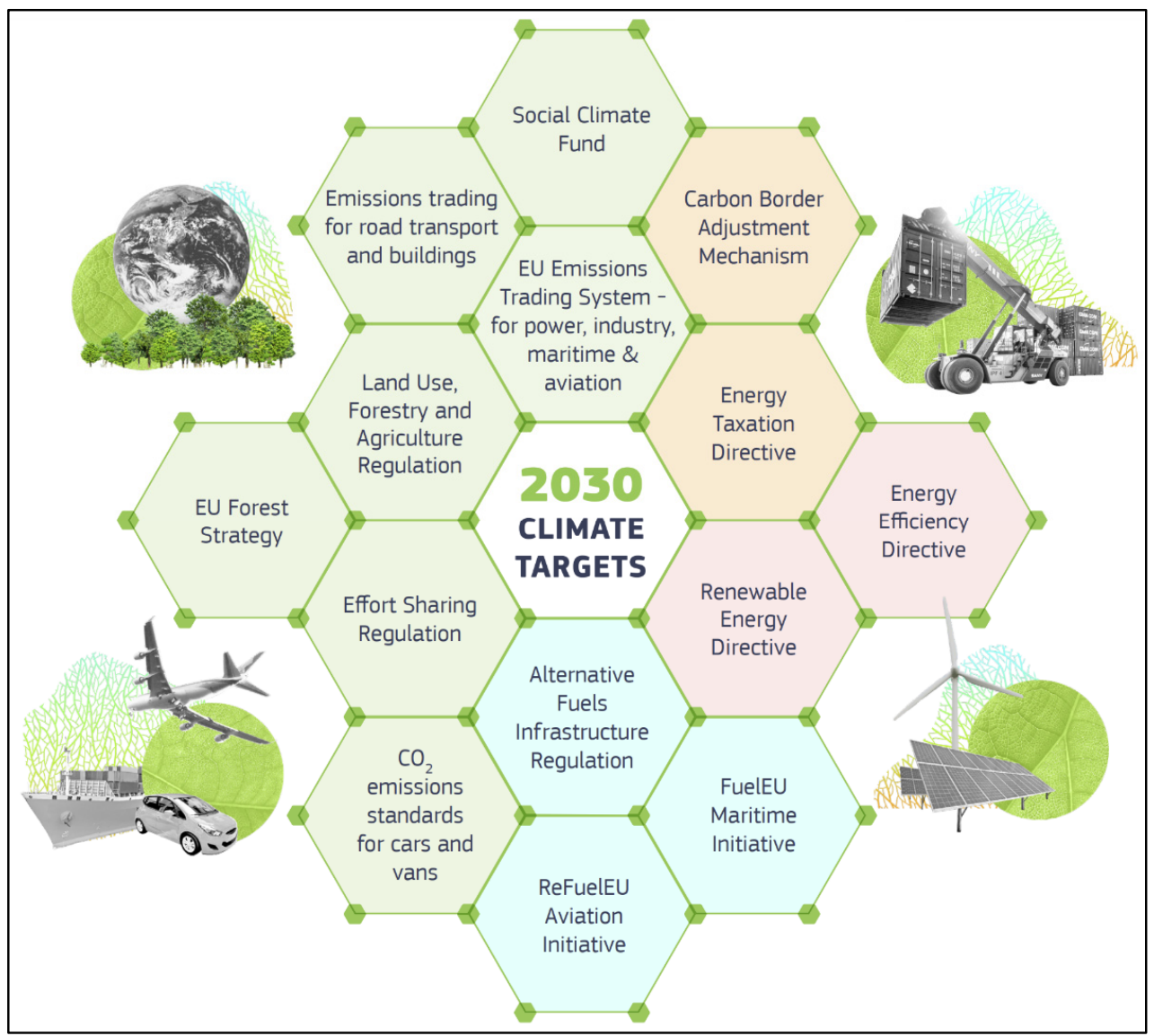

Figure 1. The "Fit for 55 package". Source: [12] @ European Union, 2021 CC BY 4.0.

The markets are changing based on the development of the environmental perception in society $[1,12]$. This is also the case for the structure of the labour market and various work positions. Transforming current economic structures into a sustainable economy is a complex process, determined by the type of jobs, including green jobs [19]. For example, we can observe the greening of the agricultural sector. On the one hand, it contributes to creating new green jobs. On the other hand, this leads to the upgrading of existing ones [20]. Significant employment increases are expected in resource renewal, earth repair and, to a lesser extent, environmental survey and clean green agriculture.

\subsection{Multidisciplinary Teaching Approach}

Concerning sustainable business development, all possible indicators should be part of business models. A sustainable or green economy depends on the interactions of land and natural sources and the locations of the businesses, their employees and customers. Therefore, both geospatial data analysis and financial and non-financial performance measurement and analysis of companies are valuable for sustainable business development. In companies, calculations are typically performed for process optimizations and cost efficiency. By considering the geo-location in such calculations, many benefits can be achieved that also account for aspects beyond profit. The application of geospatial methods in economics is a rather new interdisciplinary approach. It seems necessary to establish new teaching concepts that focus on interdisciplinary knowledge as well as on data literacy skills [21]. It raises student's awareness for a sensible use of data with performing analyses and for presenting their results.

Developing such a new teaching approach starts with a proper literature review. Working with the international scientific database Web of Science unveils interesting scientific studies (using the keywords multidisciplinary, economy, GIS and education). There are studies with various interdisciplinary aspects connected with economic disciplines. For 
example, the author of [22] studied collaboration patterns in higher education research using the Scopus database applying the gravity model. His findings can foster multidisciplinary research.

Another interesting study [23] presents the results of theoretical justification and practical verification of modern possibilities of using the pictorial method (museum tours) in teaching the subject The History of Economics and Economic Thought. The virtual museum as an informational resource, multimedia phenomenon and cost-effective model of museum space was considered, and the educational experience of the EU countries was studied. The authors present pedagogical products, such as regional thematic tours, the methodology of using online resources of Ukrainian museums (virtual tours, virtual exhibits) and results of the independent work of students.

A multidisciplinary approach is important in the education of environmental topics and tasks, such as floods, renewable energy sources, pollution and sustainability. An interesting study in this field was presented by the authors of [24]. The authors conducted a field study focused on the impacts of the Lumber River flooding in Lumberton, North Carolina. Besides other results, they focused on a multidisciplinary approach and linkage between engineering-based flood damage assessments and social science-based household interviews. These interviews captured socio-economic conditions, for example, social vulnerabilities related to race, ethnicity, income, tenancy status and education levels. Another study in the environmental field was published by the authors of [25]. The authors researched aspects of sustainability connected with engineering education. The paper describes the results of the Iberian project, based on project-based learning and teamwork methodologies, promoting the development of transversal skills and addressing sustainability in a multicultural and multidisciplinary background. As a result, students involved in the project are aware of the social, economic and environmental impact of their semestral projects, in terms of quality of life, social responsibility, the use of resources, and environmentally friendly technology.

Dealing with environmental topics, economic aspects and technical/engineering education, we can find many possibilities for a multidisciplinary approach in teaching and learning methods. For example, the authors of [26] focused on a new model of managerial education in technical universities and education systems with the involvement of online study modes, based on the multidisciplinarity and adaptivity of educational technologies. The presented model of managerial education integrates two blocks of the educational process, engineering and economics, as well as including modern technologies of teaching. The model of engineering and managerial education allows engineers of a new type to be trained. Such engineers will be able to adapt to new tendencies and initiate the necessary changes for the effective functioning of business under the conditions of the digital economy.

Another study [27] in technical field education presents a novel multidisciplinary undergraduate course on alternative energy engineering. The course design includes lectures, laboratories and a hybrid power system design project focusing on the economic integration of alternative energy in power systems, such as solar thermal, solar photovoltaic, wind, hydroelectric and fuel cell energy sources. Societal needs are addressed through a focus on industry structure, technology, economics and connected policies.

For good results in the teaching and learning processes, the methodological approach represents a significant variable. It is connected with the abilities and creativity of the teachers, the structure of lessons and courses and methodological innovations. Such innovative approaches were studied by various authors, for example, the author of [28]. He focused on innovation and creativity as the key factor of a teaching project. The development of teaching courses, including teaching and learning materials, is a necessary condition for the know-how transfer and a multidisciplinary approach in several subjects. The author of [28] underlines the important role of information and communications technology (ICT) and virtual environments. Another innovative approach is represented by gamification. The authors of [29] provide a proper literature review on scientific studies in the field of 
multidisciplinary approaches and gamification, published between 2010 and 2016. Close to 2000 peer-reviewed English language journals and conference papers were identified across 11 databases and categorized by discipline. Results indicate an explosive growth of literature peaking in 2015. Early on, Information and Computing Science dominated the field, to be overtaken by the sum of other disciplines in 2013-education, economics and tourism to be specific. This review indicates that gamification was initially a field within computer science and human computer interaction (HCI) and has only recently become multidisciplinary.

A multidisciplinary gamification approach or game-based learning (e.g., [30,31]) considering sustainability issues is the main scope of this paper.

\subsection{SPATIONOMY Project}

To create and test such new multidisciplinary teaching concepts, the ERASMUS+ project, SPATIONOMY ("Spatial exploration of economic data-methods of interdisciplinary analytics") [32], was set up. Other studies such as [33-35] describe its conceptual framework in more detail. An interdisciplinary team of researchers and academic lecturers developed and tested a new teaching approach based on playful learning. They represent the fields of geography/geomatics/geoinformatics-during the project generally referred to as "geo" — and economy/business and informatics/business management—in the project ordinarily referred to as "eco". The aim was to convey interdisciplinary methodological skills to students at the interface between geomatics and economics. Besides the teaching of basic knowledge in the two thematic fields, the central elements of the teaching concept are case studies and a simulation game with interdisciplinary challenges. Here, the students apply their basic knowledge gained during a preparatory phase to solve several rounds of game-based learning.

The design of the simulation game, created in the SPATIONOMY project, is described in the studies performed by $[35,36]$. As the authors underline, simulation games, as a method of playful learning, have been used for more than 70 years in various disciplines (e.g., [37]). The SPATIONOMY simulation game merges the disciplines of "geo" (geoscience) and "eco" (economics). The authors discuss the design process that went into creating the game as well as experiences from play sessions concerning the increase in interdisciplinary knowledge among students. Other aspects of the SPATIONOMY project are discussed in a study by [38]. The authors analysed the students' attitudes towards interdisciplinary knowledge using the technology acceptance model (TAM) framework [39,40]. Based on the results, the students included in the project in practice gained recognition of systems thinking. They were able to realise the importance of mutual interdisciplinary cooperation towards achieving synergies. The results also show that TAM can be successfully implemented to analyse how students from the fields of "eco" and "geo" accept the use of interdisciplinary knowledge in the learning process. It is an important aspect for management and education as well as the theoretical implications.

From the teacher's perspective, one main aim was to prepare innovative digital interdisciplinary teaching materials and game-based teaching that covers the areas mentioned above. The game-based approach combines personal attitudes and opinions as well as knowledge on the topics of SPATIONOMY with given financial and non-financial data and inputs. Thus, interlinking decisions with outcomes such as cash flow, pollution, impacts on employees, exposure to natural hazards, etc. This multidisciplinary approach is a great benefit of game-based teaching, as it can be applied in various classes [41]. Another important aspect is the ability of game-based teaching to enhance student's engagement [42].

In sustainable business issues, education, including gamification, can help with serious problems, such as long-term unemployment and support of regional economy. This is the focus of a study performed by the authors of [10] and her team. Based on their results, gamification can improve the motivation and engagement of stakeholders.

Moreover, serious games intend to evaluate the learning process as well as the outcomes. Based on [43], the purpose of a serious game is twofold: (1) to be fun, and (2) 
to be educational. Serious games are designed to support knowledge acquisition and skill development.

\section{Materials and Methods}

Economic data analysis plays an important role in the decision-making processes of companies. In this context, geodata and spatial aspects [44] gain more and more attention. Thus, it is of great importance to harness the benefit of spatial analysis with economic analysis. In addition to that, the education of students needs adjustments toward such new content. Therefore, in the SPATIONOMY project, the aim was to improve the interdisciplinary skills of the participating students by creating a mutual understanding for the participating disciplines economy, business informatics, geomatics and geography. To reach this goal, the students became participants in a simulation game aimed at solving interdisciplinary problems by structuring a group-based and student-led analysis of appropriate economic and spatial data. As a preparation for the simulation game, students participated in preparatory learning blocks. Therein, practical cases of both economics and geomatics analysis were practised to bring students of the different study backgrounds together and to encourage them to exchange knowledge and experience of their respective scientific fields.

The teaching concept used in the SPATIONOMY project consists of different parts, as outlined in Figure 2.

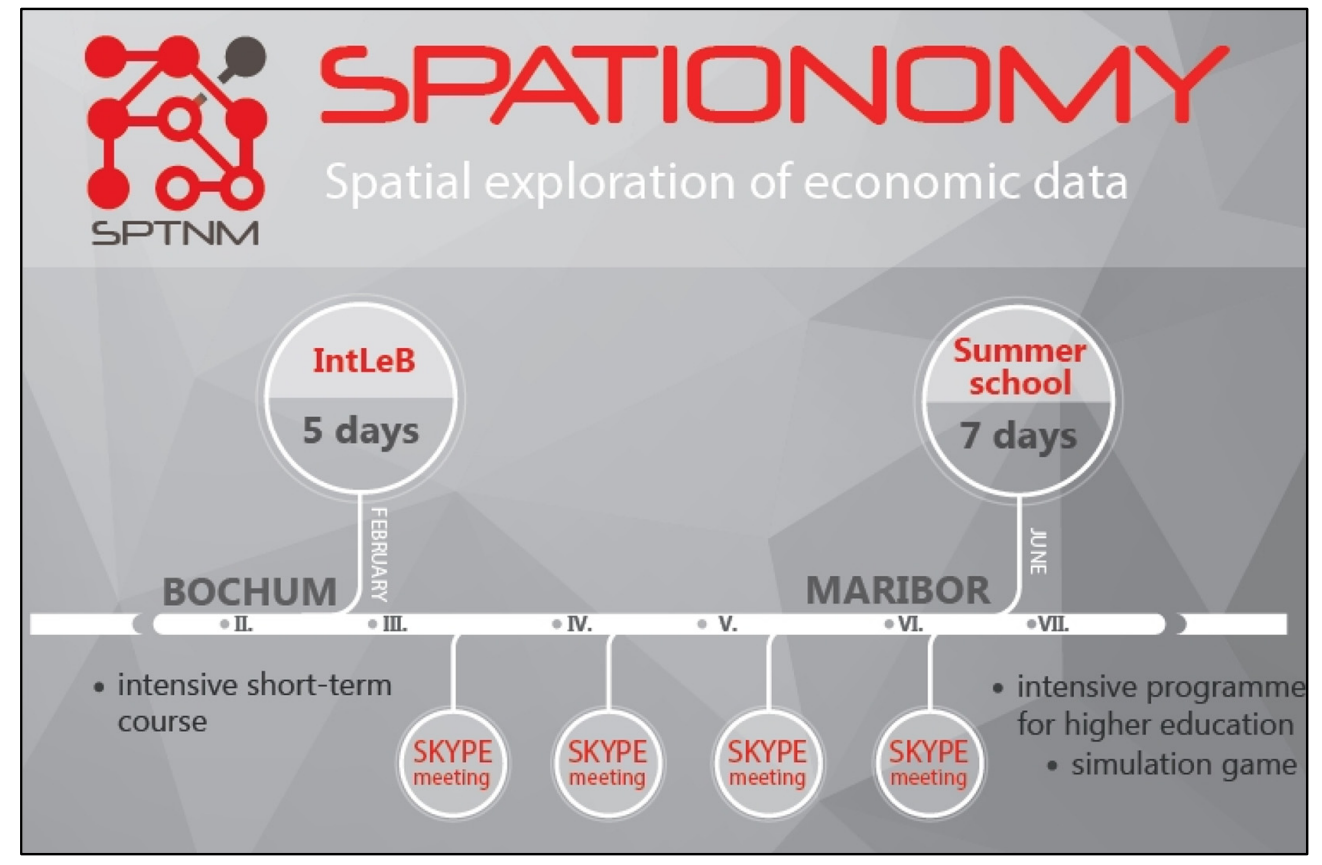

Figure 2. Structure of SPATIONOMY (Source: [33]).

Each cycle with a new cohort of 28 students started with a so-called "scientific laboratory" (SciLab) with the teachers to prepare the "interdisciplinary learning block" (IntLeB) for the students. This blended mobility block lasted for five months. It consisted of the following three components: two short-term courses with physical attendance of students and teachers and, in between these, virtual monthly meetings to support the work on a chosen project. The first short term course with mandatory physical attendance of all participants (commonly called "drill") aimed to provide basic knowledge for the students in different scientific fields: lectures on economy, management, and geomatics. As a result of the "drill", students ought to have knowledge about the following topics [33]:

- Data sources of spatial and economic data;

- (Geo)data formats (e.g., raster vs. vector); 
- Open data policy and open data sources;

- Statistical data sources and primary data sources (e.g., from companies);

- Quantitative methods in economy (e.g., descriptive statistics, random sampling, multiple regression analysis, discriminant analysis);

- Spatial analysis (e.g., geocoding, buffering, map algebra, surface analysis, visibility analysis, network analysis, geostatistics, interpolation, pattern analysis);

- Business informatics principles (e.g., business informatics solutions concepts, enterprise resource planning with GIS integration, support for real time decisions, business analytics);

- Methods in micro- and macroeconomic modelling (e.g., marginal variables, utility functions, equilibrium models, agent-based modelling, long-term models);

- Finance and business principles (e.g., financial performance measurement, Balanced Scorecard, net present value);

- Data visualization techniques (e.g., non-spatial visualization with graphs, charts, plots, etc., spatial visualization and map composition, interactive visualization with web maps).

As a summary, during the "drill" part, the "geo-students" gained "eco"-related knowledge and vice versa the "eco-students" gained "geo"-knowledge. At the end of the first short term course, and based on this knowledge, the students started the distance learning part of the IntLeB, which comprises a first project in the student's groups. That project was assigned to be worked on during the virtual project phase. Each of the seven groups of students was composed of members from all four participating universities and all scientific disciplines to foster international and interdisciplinary project work. Each team had supervisors from the group of teachers assigned for assistance.

An important side effect, yet intentional, of the drill part was to also bond students within and across the teams, to support their social interactions, as the following part of blended learning was without physical contact. The drill engaged the students into the social network and, thus, improved their performance during the blended stage. Prior studies already observed this effect, for example [45].

The main element of the project was the intensive summer school (7 days). It started after the virtual course period. The first action there was to present the group project results gained during the virtual part. Then, the summer school provided further in-depth theoretical and practical knowledge of all academic fields (advanced business informatics, advanced statistical and decision-making techniques, advanced spatial analysis and modelling, interactive visualization, map-design), aiming to use this knowledge in an interdisciplinary simulation game.

The following paragraphs will focus on the additional value of the simulation game as an interdisciplinary teaching approach for sustainable business development in more depth.

The interdisciplinary simulation game is based on a simplified real city scenario. In the game, each group of students inherits a large amount of money from their ancestors linked to the task to produce innovative bicycles. Bicycles are closely connected to sustainability and the lifestyle of young people at the same time. Thus, dealing with bicycles is close to the students' living environment and links it to the sustainability background of the project.

The inherited amount of money represents the basis for funding a new company. To start this new enterprise, firstly, the groups need to find a suitable property in the city. Both economic and spatial criteria need consideration to find an optimal location. Secondly, the groups of students have to plan the company's size by defining the number of employees and its productivity. The latter is achieved by setting a price per bicycle and an estimated number of bicycles to be produced per annum. This part is basically of economic nature.

After founding the company, six more rounds of the simulation game follow to address various interdisciplinary issues, such as economic, managerial, environmental or spatial issues.

To further run the company, the groups of students have to find solutions to overcome various challenges, such as new pollution/emission limits, pollution allowances 
implementation, risk management and floods, site analysis for a reseller shop, renewable energy investments, etc. To continue a successful business, students apply various kinds of interdisciplinary tools. The simulation game focusses on the application of the gained interdisciplinary knowledge, including geospatial tools and quantitative economic methods. Each round of the simulation game is supervised and evaluated by a team of teachers. Credits/points are given according to the performance of the teams.

The essential steps in the simulation game can be defined as follows: Each team inherits a certain amount of play money. It founds a company that produces bicycles with a focus on the following:

1. Spatial approach (related to site analysis): location, environment;

2. Economic approach (related to income and expenses): company size, number of employees, prices, bicycle concept, etc.

Many constraints are given to foster interdisciplinary analytical skills. In addition to that, students had to develop a marketing strategy, invent a brand name with an attractive logo and establish a dashboard for their company.

The winning team is identified based upon performance during all rounds, ending in a "Grand Finale": the Dragon's Den. Adopted from the TV show, the student teams had to promote their companies to a group of investors (represented by teachers) and negotiate for an adequate price for the share offered to the investor. The resulting money will be added to their overall cash balance to finally find out which group was the most successful after all rounds.

While the first rounds deal with rather practical and technical aspects and proper planning, this last round offers the chance to interact with investors to receive the best possible investment to support the further growth of the company.

The described structure can be summarized in Figure 3.
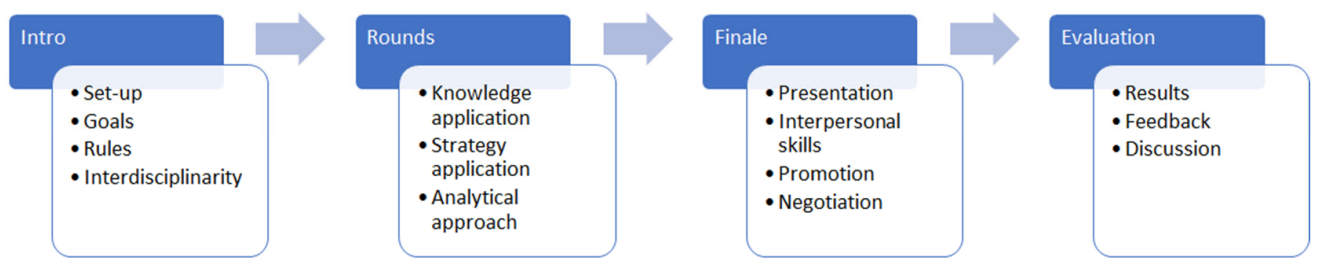

Figure 3. Structure of simulation game (Source: Authors).

Based on the mixture of interdisciplinary approaches and the playful simulation game, students become specialists in so-called "spatial economy". After this course, students are able to apply this knowledge in their future business life and career.

One key educational goal of the simulation game is to introduce a multidisciplinary approach to sustainable business development. Therefore, data related to the simulation game require a multidisciplinary approach, as they consist of economic, financial, social, environmental, geolocational and geographical sets, thus balancing the approach and also driving the student's attention towards all of these aspects.

For this, teachers discussed the selection of four indicators to keep it simple yet covering various areas. Thus, they made it clear at the beginning of the simulation game that they include the indicators listed in Table 1 in the evaluation.

The evaluated categories can be in conflict (e.g., higher investment decreases cash flow, higher production generates higher sales and higher pollution simultaneously). Therefore, students need to balance their decision making by using the multidisciplinary approach. 
Table 1. Observed indicators and their description (Source: Authors).

\begin{tabular}{cc}
\hline Indicator ${ }^{1}$ & Description \\
\hline Investment & $\begin{array}{c}\text { Economically oriented indicator (capital investment). It observes the value of the } \\
\text { assets. However, a high level of this indicator will have a negative impact on the } \\
\text { cash flow. This indicator was introduced to students as a representation of the } \\
\text { value of the company and also the stability of the company. }\end{array}$ \\
\hline Cash Flow & $\begin{array}{r}\text { Financially oriented indicator. This indicator was introduced as the financial } \\
\text { sustainability measure. }\end{array}$ \\
\hline Employees & $\begin{array}{r}\text { Socially oriented indicator. This indicator was introduced as the measure of } \\
\text { social impact: how many people are breadwinners due to the company. }\end{array}$ \\
\hline Pollution & $\begin{array}{l}\text { Environmentally oriented indicator. The level of pollution represents the impact } \\
\text { of the business operating on the market. The pollution is affected by the size of } \\
\text { the company and the volume of its production. }\end{array}$ \\
\hline
\end{tabular}

${ }^{1}$ Green indicator is positive (the higher the better) and red indicator is negative (the lower the better).

The multidisciplinary approach of the simulation game is based upon the following mind map (Figure 4) (derived from the description of the indicators evaluated):

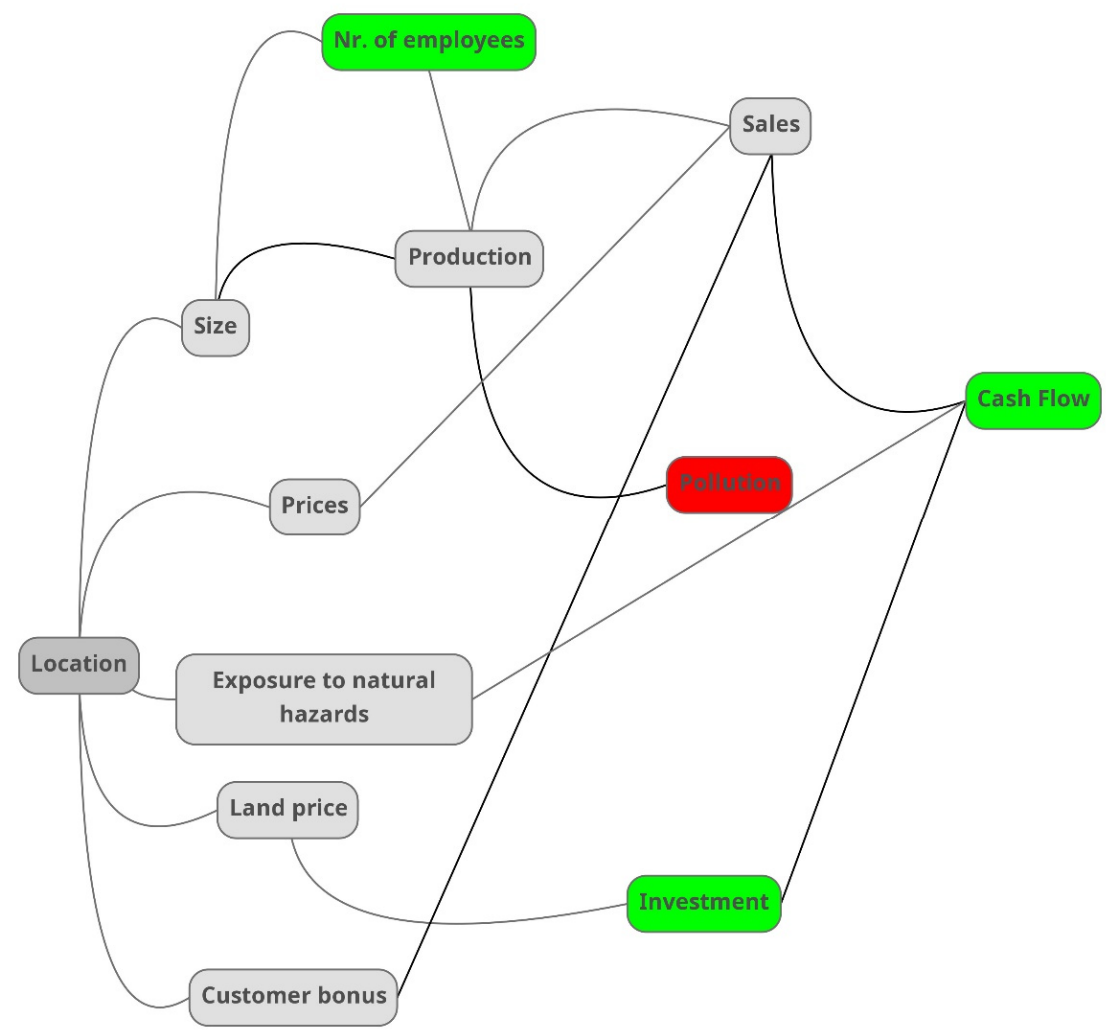

Figure 4. Mind Map of SPATIONOMY simulation game. Green indicators are positive (the higher the better) and red indicators are negative (the lower the better) and of course, as mentioned above, categories are not independent, which is why students had to balance their decisions from various perspectives. (Source: Authors).

\section{Results}

This part will present the results of the simulation game for sustainable business development, using selected outputs from the SPATIONOMY project summer schools conducted in the period 2017-2019.

The first significant result is the acceptance of the interdisciplinarity approach by students. In all the rounds, students had to balance several aspects and use the knowledge 
from all the involved disciplines. The location of their company affected its financial performance, its size and volume produced, the emitted pollution and the number of employees.

The students understood the bonuses for locating the company near the commercial zones in the city very well (and all the teams were able to obtain these bonuses). The students used the knowledge of geoinformatics and business and were able to work with real-world data represented (not only) by the map of an existing city, as shown in Figure 5.

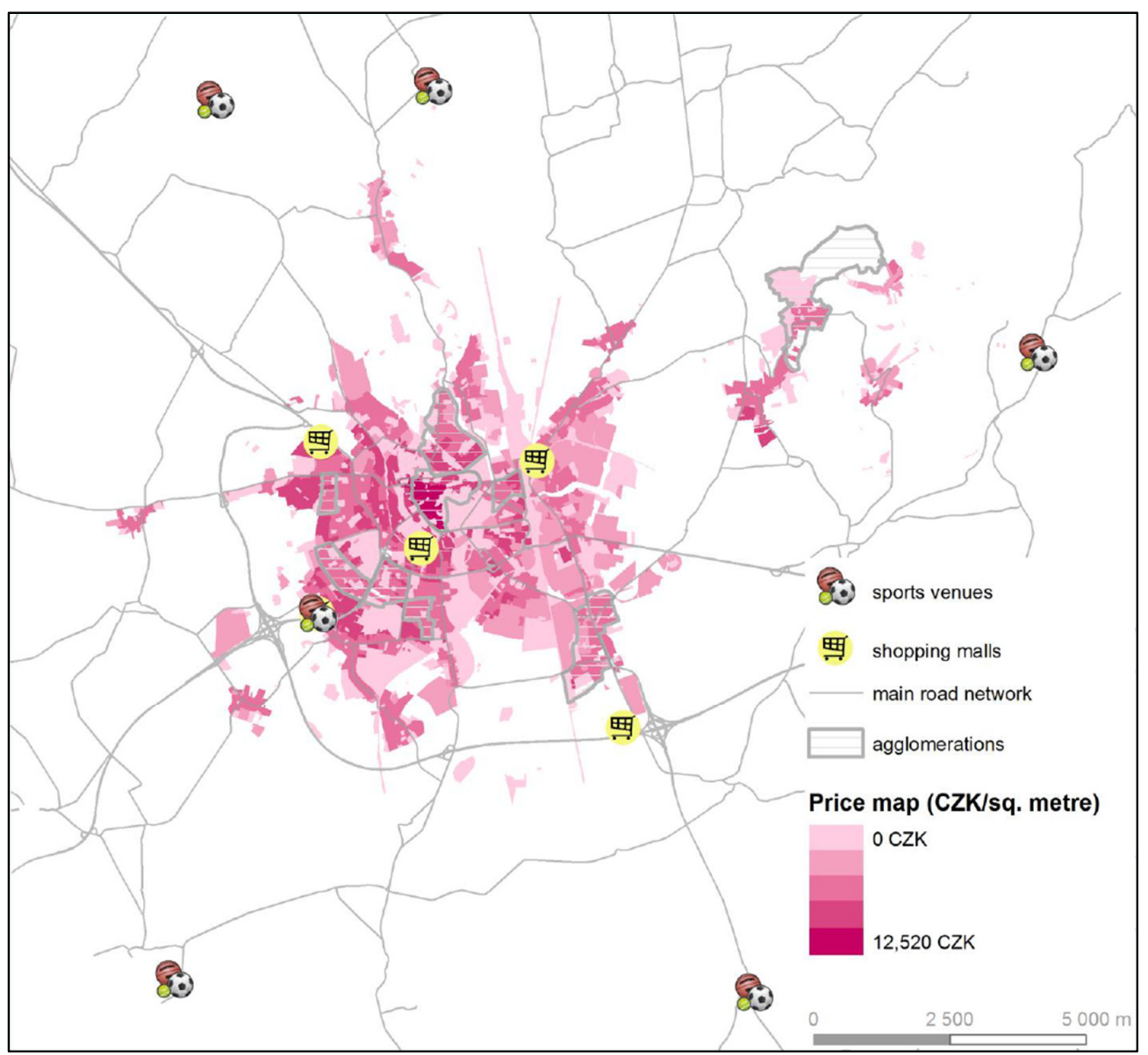

Figure 5. Map of Olomouc (Source: [35]).

As already shown in the mind map in Figure 4, all the observed indicators are (positively or negatively) interlinked. Even though the first round looks similar to a spatial problem (Where to locate the company?) and a slightly economical problem (What size of the company?), students adopted a multidisciplinary approach and (during feedback) stated several other perspectives.

For the students, the ecological and sustainability approach was quite substantial. They tried to reduce the pollution, despite the financial perspective. Additionally, the social aspect was essential to them. They decreased or minimized the negative impact on residents in the area. One team even went beyond the starting conditions and increased the wage for employees. It harmed the team financially, but yet students appreciated the social impact.

Examples of the observed values after the first round of the simulation game in 2017 are presented in Table 2. Based upon the values, the teachers evaluated student teams and assigned points to the teams. Each round was evaluated based upon several different achievements. 
Table 2. Initial decisions of the teams after the first round of simulation game (Source: Authors).

\begin{tabular}{cccccccccc}
\hline Team & $\begin{array}{c}\text { Size } \\
\mathbf{( m}^{\mathbf{2}} \mathbf{n}\end{array}$ & $\begin{array}{c}\text { Unit } \\
\text { Production }\end{array}$ & Sales EUR & Bonus & $\begin{array}{c}\text { Salaries } \\
\text { EUR }\end{array}$ & $\begin{array}{c}\text { Investment } \\
\text { EUR }\end{array}$ & $\begin{array}{c}\text { Cash Flow } \\
\text { Total EUR }\end{array}$ & Employees & Pollution \\
\hline T1 & 833 & 3000 & $7,276,500$ & 1.16 & $2,799,000$ & 691,667 & $1,406,683$ & 250 & 3000 \\
\hline T2 & 833 & 3000 & $7,623,000$ & 1.21 & $2,799,000$ & 916,667 & $1,528,183$ & 250 & 3000 \\
\hline T3 & 100 & 360 & 958,320 & 1.21 & 335,880 & 110,000 & 226,942 & 30 & 360 \\
\hline T4 & 100 & 120 & 333,960 & 1.21 & 111,960 & 75,000 & 51,834 & 10 & 120 \\
\hline T5 & 250 & 600 & $1,597,200$ & 1.21 & 559,800 & 211,200 & 350,370 & 50 & 600 \\
\hline T6 & 850 & 3000 & $7,276,500$ & 1.16 & $2,799,000$ & 935,000 & $1,163,350$ & 250 & 3000 \\
\hline T7 & 834 & 3000 & $7,623,000$ & 1.21 & $2,799,000$ & 417,000 & $2,027,850$ & 250 & 3000 \\
\hline
\end{tabular}

The table shows different approaches to the decision. The theoretical best size (from the financial perspective) of the company was 833 square meters. Some teams (such as T4) preferred low pollution (smaller company) and, thus, low production. Some teams (T1, T2, T6, T7) preferred large production and, thus, high pollution. Other teams (T3, T5) balanced their decisions and preferred medium production and medium pollution. In other words, three out of the seven teams (42.9\%) did not prefer to maximize production (and financial performance) over pollution. It demonstrates how the students approached the decision from many angles and included (and balanced) various aspects, not all necessarily mentioned in the setup for the first round. This suggests that the pollution is an important topic for students, even though the game design was in favour of cash flow. The column "Bonus" represents the ability of the students to properly use the geoinformatics tools (GIS), as all the teams were able to obtain the bonuses for choice of location (the number in this column is higher than 1.00).

While sustainability has been part of the decision making all the time during the simulation game, in 2018 and 2019 there was a whole round dedicated to renewable energy. (The first run of the project was the initial developing and testing phase of the game. Based on its experience, further rounds were added in the following iterations. That is why only the years 2018 and 2019 are fully comparable and if a comparison is used, these two years are involved.) The student teams were given the task of investing in solar and wind power energy sources and assessing their decision using the Net Present Value (NPV). They had to consider the investment expenditure (how much to invest), location (based on information about the wind and number of sunny days during the year), energy prices and energy production. Again, this round is designed to demonstrate how decision making is a multi-perspective issue and how several aspects need to be considered. In this round, sustainability is a multidisciplinary issue. The students submitted their results and were evaluated based upon them. Results of this rounds (2018 and 2019) are presented in following Tables 3 and 4 . The nature of this round demonstrates the interdisciplinary approach as the students were handling sustainability, while being restricted or limited by geographic factors and geomatics (they had to find suitable areas from the perspective of annual wind days and annual sunny days) and finance (the investment had to be financially sustainable, measured by the Net Present Value in column NPV). The values in the column NPV show that all the students were able to balance these perspectives as all the NPV values are positive.

The round was evaluated through the criteria of (1) correct calculation, (2) location for the solar plant/wind turbines and (3) financial impact on the company through the NPV. The "real" financial impact was calculated by the teachers, as some teams made mistakes during their calculations. Hence, their NPV was not the one "truly" achieved based upon their decisions. That is why even the teams with the same NPV (or even higher ones than other teams) were not evaluated with the same rank. This happened in both years, in 2018 and 2019. 
Table 3. Data related to the NPV calculation for renewable energy 2018 (Source: Authors).

\begin{tabular}{ccccccc}
\hline Team & Name & Cash Start & Operational Cash Flow & Net Present Value & Cash Closing & RANK \\
\hline 1 & T1 & EUR 3,770,740 & EUR 952,740 & EUR 42,409 & EUR 4,763,344 \\
2 & T2 & EUR 1,626,665 & EUR 752,665 & EUR 47,865 & EUR 2,427,194 \\
3 & T3 & EUR 4,135,480 & EUR 1,905,480 & EUR 47,865 & EUR 6,088,825 \\
4 & T4 & EUR 3,279,540 & EUR 826,740 & EUR 47,865 & EUR 4,134,999 \\
5 & T5 & EUR 3,049,614 & EUR 124,074 & EUR 47,865 & EUR 3,204,800 \\
6 & T6 & EUR 2,655,395 & EUR 202,595 & EUR 84,276 & EUR 2,942,267 \\
7 & T7 & EUR 3,071,962 & EUR 1,521,202 & EUR 84,276 & EUR 4,677,440 \\
\hline
\end{tabular}

Table 4. Data related to the NPV calculation for renewable energy 2019 (Source: Authors).

\begin{tabular}{cccccc}
\hline Team & Name & Cash Start & Operational Cash Flow & Net Present Value & Cash Closing \\
\hline 1 & T1 & EUR 5,210,066 & EUR 548,370 & EUR 100,337 & EUR 5,858,773 \\
2 & T2 & EUR 4,839,706 & EUR 350,370 & EUR 47,864 & EUR 5,237,940 \\
3 & T3 & EUR 11,692,788 & EUR 2,381,850 & EUR 100,337 & EUR 14,174,975 \\
4 & T4 & EUR 12,096,790 & EUR 2,381,850 & EUR 84,276 & EUR 14,562,916 \\
5 & T5 & EUR 5,481,081 & EUR 548,370 & EUR 84,276 & EUR 6,113,727 \\
6 & T6 & EUR 8,516,762 & EUR 1,629,185 & EUR 100,337 & EUR 10,246,285 \\
7 & T7 & EUR 5,075,156 & EUR 800,302 & EUR 100,337 & EUR 5,975,794 \\
\hline
\end{tabular}

Similar procedures took place after each round: evaluating the teams based upon their work and the results they submitted to the academics. The overall score of the teams was calculated at the end of the simulation game. The results of the years 2018 and 2019 are presented in Figures 6 and 7. While those figures may seem slightly chaotic, they represent the results of the teams during the rounds truthfully. The more diverse the lines are, the more teams alternated in being the first in a particular round while being the last in another round. The worst case scenario is a set of levelled parallel lines, which definitely did not occur. The rightmost part of both figures (separated by the thick black line) represents the final position of each team. In other words, the more peaks and valleys and sloped lines are in the figure, the more diverse the results of the teams during the game, and the more teams experienced success and failure as well.

The results of the simulation game show a rather balanced performance of the teams. Theoretically the winning team can achieve the best score of seven times first place in every round $(7 \times 1)$; therefore, the best score is 7 . The worst possible score is losing in all rounds and being last seven times $(7 \times 7)$; hence, the worst possible score is 49 . Based upon this, the maximum difference between the first and last team is 42 points. The results are presented in Table 5 .

Another remarkable result of the simulation game was the variety of approaches used by the students. The evaluated indicators are not weighted; they all have the same importance. However, the students consciously projected their own attitudes and preferences into the game, and they did imply the weight or importance of the indicators. For example, more socially oriented students (or teams) preferred to act in a social-friendly way, despite the loss of the score in other perspectives. These teams were satisfied with the results, even though they did not score best in a particular round.

On the other hand, the competitive nature of the game helped the students to get more engaged and enabled a more intense game experience. 


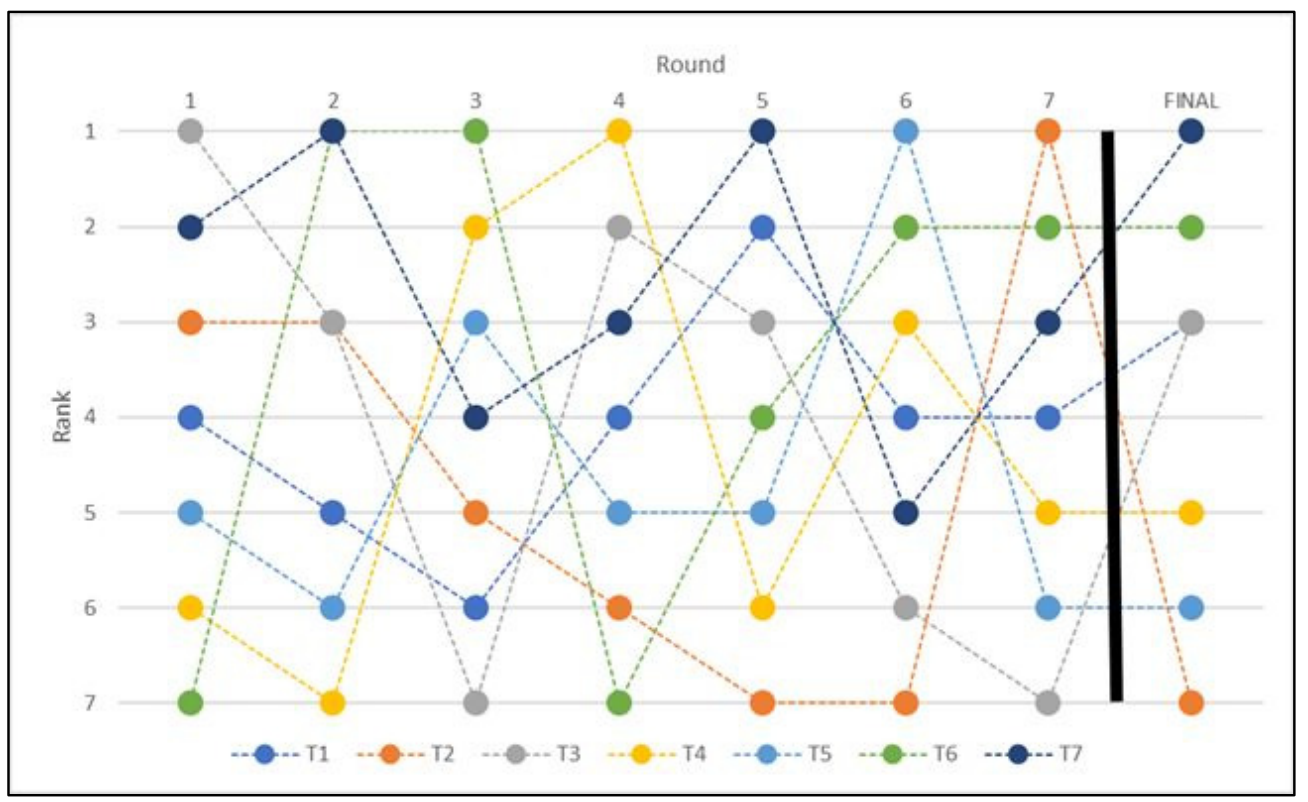

Figure 6. Team positions during the simulation game 2018 (Source: Authors).

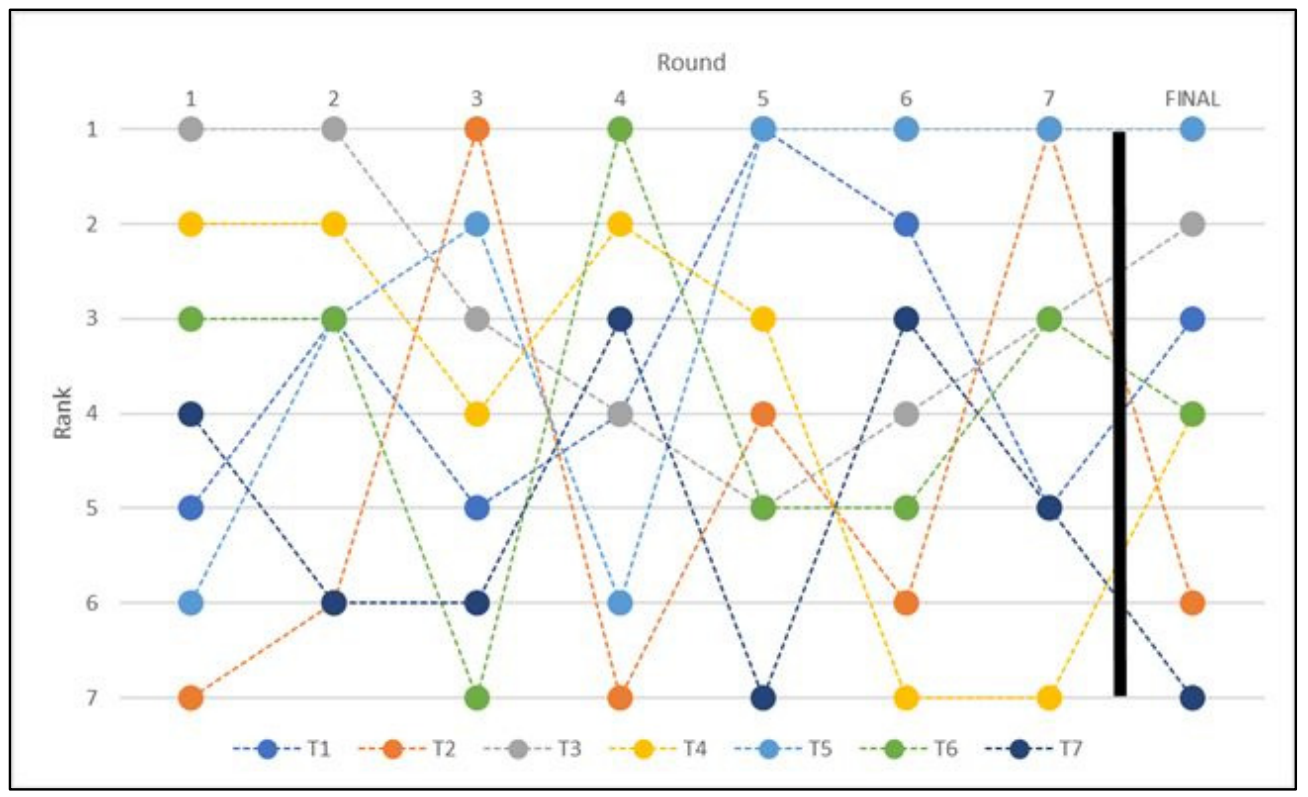

Figure 7. Team positions during the simulation game 2019 (Source: Authors).

The Maximum spread describes how far the score of the best and the last team is. The theoretical maximum for this statistic is 42 . However, we can see that in both years it has been significantly lower. It suggests that teams were quite even: There was no clear winner or loser. This is also supported by the Best score of the winning team in both observed years-it is 19 and 20 (not a big difference between the years). It suggests an average value (Best AVG) of 2.71 and 2.86. In other words, the average position for the winning team is slightly better than being third and significantly below being second.

Table 5 also shows a small difference between Best AVG and Median AVG (1.43 in 2018 and 1.00 in 2019), again confirming that the difference between teams was rather small.

The presented results suggest that there was no clear winner or loser in the simulation game. All the teams experienced ups and downs. This indicates that the rounds in the simulation games were truly multidisciplinary, not favouring one type of knowledge or attitude. 
Table 5. Basic description of simulation game results of 2018 and 2019 (Source: Authors).

\begin{tabular}{ccc}
\hline Characteristic & $\mathbf{2 0 1 8}$ & $\mathbf{2 0 1 9}$ \\
\hline Max spread & \\
Best $^{2}$ & 13.00 & 14.00 \\
Best AVG $^{3}$ & 19.00 & 20.00 \\
Median $^{4}$ & 2.71 & 2.86 \\
Median AVG $^{5}$ & 29.00 & 27.00 \\
Last $^{6}$ & 4.14 & 3.86 \\
Last AVG $^{7}$ & 32.00 & 34.00 \\
\hline
\end{tabular}

${ }^{1}$ difference of scores between first and last team; ${ }^{2}$ score of the first team (the smaller the better); ${ }^{3}$ mean value of the Best calculated as the arithmetic average; ${ }^{4}$ median score, score of the team on the 4th position out of 7 teams; ${ }^{5}$ mean value calculated as the arithmetic average; ${ }^{6}$ score of the last team and ${ }^{7}$ mean value calculated as the arithmetic average.

Regarding the students' engagement, the simulation game was a great success. Not only was it evaluated as the best part of the summer school and the whole SPATIONOMY project, but the simulation game also demonstrated how deeply students immersed in the game. We experienced several situations, especially in rounds when students' teams had to negotiate with each other or make a deal on something (cooperation, sale of the emission allowances, etc.). Then, students ceased to distinguish between the simulation game and reality. This engagement was of a positive and negative nature at the same time. Some teams experienced really heated and emotional discussions and nerve-wracking negotiations. They experienced huge disappointments when the partner did not keep the deal and realized a transaction with another (third) team. This experience expresses the need of being able to not only engage students in the simulation game but also to be prepared to disengage them as well.

To sum up, students are able to learn many new methodological approaches from the different disciplines in the project and they can also apply them. The application with time pressure in the frame of the simulation game is a good stress test. However, all the students solved their research tasks according to the required academic level.

\section{Discussion}

Based on the results presented in the previous chapter, we can say that game-based learning represented by the simulation game is both a successful teaching concept and methodological approach. In connection with current economic developments, a multidisciplinary approach in education is necessary and decision-making of economic subjects based on various criteria is the key issue. Besides new economic trends, up-to-date environmental policy and social diversity aspects, the COVID-19 pandemic caused a great acceleration in the use of technology, the digitalisation of processes and new forms of working. It has also changed social and economic aspects of the world [9]. A huge impulse for innovation can be observed not only in the healthcare sector. Concerning all the circumstances, it is necessary to use new, modern approaches to learning and teaching methods. The SPATIONOMY simulation game idea is based on the theoretical concept of spatial economy and decision making in the city [46], where participants use all the necessary data sources for building and developing a new business.

Considering both the concept and the results of the simulation game, it is clear that different disciplines and various aspects should be considered during the decision-making, negotiation and strategy conceptualisation by the students' teams. The simulation game consists of several rounds, each round representing a specific discipline. Therefore, giving all the rounds together, the multidisciplinarity of the game is achieved.

Generally, the game is suitable for all students, despite their different fields-it can help them to understand various aspects of business development, including economic, financial, environmental, social and geographical factors. There is no one possibility, no one correct solution-more scenarios are possible, more possibilities are suitable. Students can decide to be more environmentally friendly, or decide to earn a lot of money, or decide to 
have a sustainable and socially acceptable business concept supporting employment in the city or region. Dealing with both economic concepts and modelling [47], there is not only one business goal - profit. There are also other, alternative goals [48]. The decision-making within the simulation game is based on the students' preferences.

As it is underlined in [42], an important aspect of game-based teaching is the ability to enhance student's engagement.

Within the SPATIONOMY project, a student evaluation of the simulation game was realised. The students were asked to evaluate their decision-making process within the team, the simulation game design and technical aspects of the game [35]. Concerning the students' engagement as a key aspect of game-based learning, the playfulness of the simulation game is important. Based on the students' feedback, they appreciated this teaching concept and ranked the playfulness of the simulation game with the highest evaluation within the whole SPATIONOMY course (Figure 8).

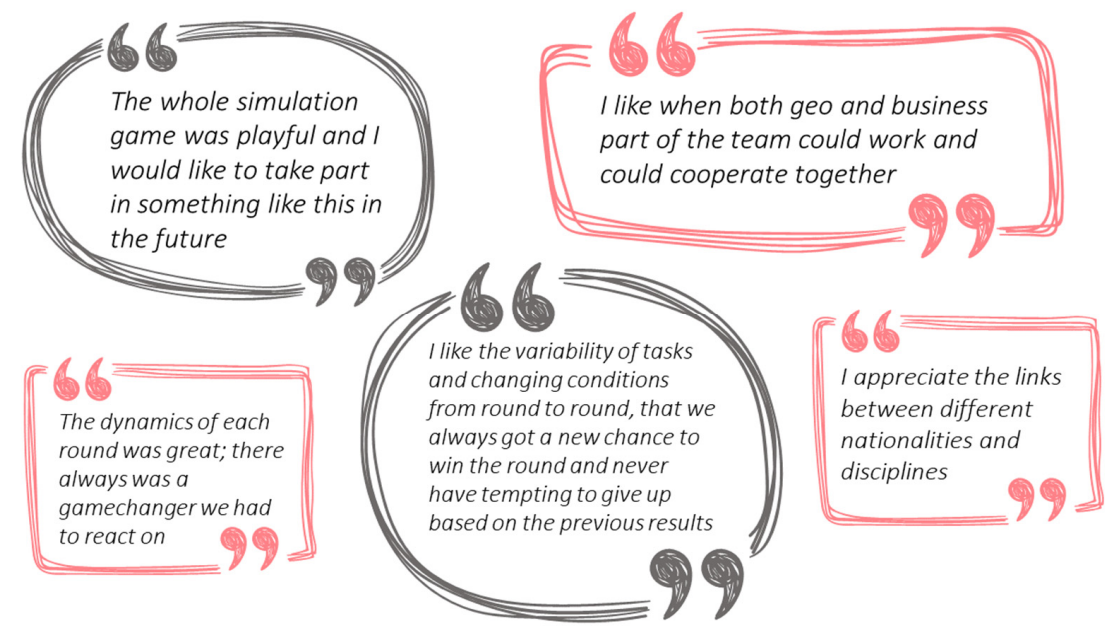

Figure 8. Examples of students' feedback (Source: Authors).

As commented by [35], the students tended to assign more positive values to the tasks where they interact with other groups, or where there is an element of surprise. Moreover, the students found the decision-making tactics and strategies the most exciting (Figures 9 and 10). Additionally, that is a part of real business life; in other words, managers and business owners need to react to many unexpected situations, negotiate and cooperate with others.

The aspects of the students' engagement, abilities and attitudes are also supported by a study performed by the authors of [49]. One of the key hypotheses focuses on students' attitudes towards the use of interdisciplinary knowledge of SPATIONOMY and its impact on their future intentions to integrate and use this knowledge. Based on the structural equation modelling (SEM) and connected analysis, the results confirmed this hypothesis. Attitudes have a direct effect on the students' intentions to use the obtained knowledge in the future.

Comparing the outputs of this paper with other scientific studies presented in the literature review, it supports the results of some previous studies. Similar to that in [25], the students involved in the course were aware of the various impacts of their projects, in terms of quality of life, social responsibility, the use of resources and environmentally friendly behaviour. 


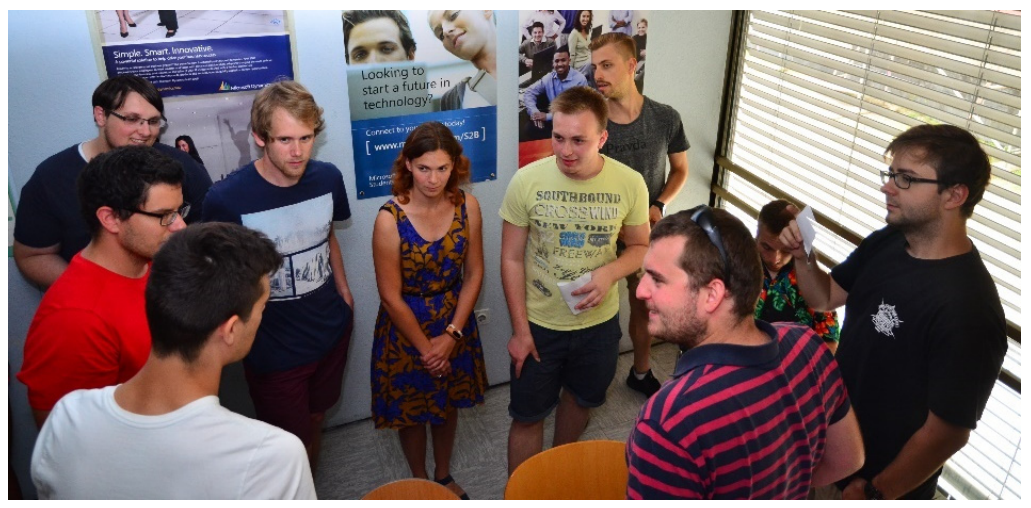

Figure 9. Pictorial impression of business negotiation in the simulation game (Source: Authors).

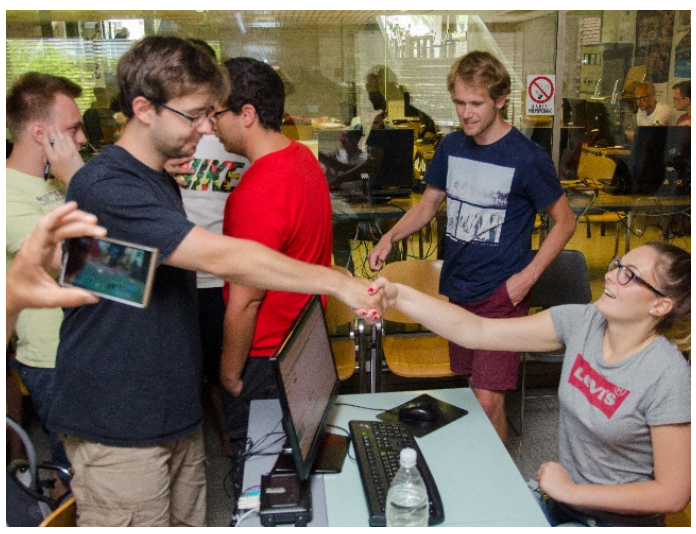

Figure 10. Pictorial impression of business decision and agreement between team leaders (Source: Authors).

Dealing with the results published by the authors of [26], the positive impacts of multidisciplinary teaching methods on the students' abilities can be underlined. In the case of [26], the participants were able to adapt to new tendencies and initiate the necessary changes for the effective functioning of business under the conditions of the digital economy. The participants of the SPATIONOMY course and simulation game were able to think outside of the box, with the multisectoral approach in sustainable business development.

Currently, the follow-up project SPATIONOMY 2.0 is being realised. The key idea represents the best output from the finished first SPATIONOMY project; it is the gamification of a learning process. The project team continues in a methodological approach and focuses on playful features in the learning process.

The project SPATIONOMY 2.0 aims to innovate the way of teaching the distinct fields of economics, business, geoinformatics and geography, all encompassed by game studies, via modern methods of informal teaching (gamification and playful education) and virtual telecollaborative techniques $[36,50]$. Generally, the project tackles the issue of learning-bydoing by playing a serious and scientifically based simulation game. In SPATIONOMY 2.0, the focus is on a higher level of integrating the students by their own creation of game rounds.

This game-based learning transforms traditional means of higher education classes into innovative, creative learning environments in which all participants (teachers and students) will be engaged in solving real-world issues through gaming scenarios.

As mentioned in the introduction, in the case of sustainable business development, all possible indicators should be part of decision-making processes. Both managers and owners of companies should consider not only financial aspects and criteria. Based on current policy issues, such as the European Green Deal [12], or other new economic trends throughout the world, all possible indicators are valuable. Such indicators are 
represented by environmental, economic, social, geospatial variables or non-financial performance measurements.

\section{Conclusions}

Generally, the main aim of this paper was to present, evaluate and discuss the interdisciplinary methodological approach as well as the results from the application of the simulation game developed and carried out in the SPATIONOMY project.

Based on the experiences with the simulation game, it is clear that the gamification of education is worthy. Simulation game-based learning appears to be more playful and experiential compared to traditional teaching. We can say that game-based learning, represented by the simulation game, is both a successful teaching concept and methodological approach.

Sustainable businesses can achieve many benefits beyond profit, practicing a multidisciplinary approach and decision making. This is the reason for the necessity of new teaching methods and approaches, such as interdisciplinary simulation games, presented in this paper.

Author Contributions: Conceptualization, C.J., J.Z., M.M. and A.P.R.; methodology, C.J., J.Z., M.M. and A.P.R.; validation, M.M. and J.Z.; writing-original draft preparation, C.J., J.Z., M.M. and A.P.R.; writing-review and editing, C.J., J.Z., M.M. and A.P.R.; visualization, A.P.R. and M.M.; supervision, J.Z. and C.J.; project administration, C.J. and J.Z.; funding acquisition, C.J. and A.P.R. All authors have read and agreed to the published version of the manuscript.

Funding: The research was supported by project no. 2019-1-CZ01-KA203-061374 Spatial and economic science in higher education-addressing the playful potential of simulation games (SPATIONOMY 2.0) and by project no. 2020-1-CZ01-KA226-HE-094425 Transferring contact, technology- and field-based education to digital: methods and tools for geosciences training (DigiGeo), both projects funded by the European Union within the Erasmus+ program.

Institutional Review Board Statement: Not applicable.

Informed Consent Statement: Not applicable.

Data Availability Statement: Not applicable.

Conflicts of Interest: The authors declare no conflict of interest.

\section{References}

1. Šebestová, J.D.; Sroka, W. Sustainable development goals and SMEs decisions: Czech Republic vs. Poland. J. East. Eur. Central Asian Res. 2020, 7, 39-50. [CrossRef]

2. Pawliczek, A.; Kozel, R.; Vilamová, Š.; Janovská, K. On the strategic planning, innovation activities and economic performance of industrial companies. Acta Montan. Slovaca 2015, 20, 16-25.

3. IPCC. Summary for Policymakers. In Climate Change 2013: The Physical Science Basis. Contribution of Working Group I to the Fifth Assessment Report of the Intergovernmental Panel on Climate Change; Stocker, T.F., Qin, D., Plattner, G.-K., Tignor, M., Allen, S.K., Boschung, J., Nauels, A., Xia, Y., Bex, V., Midgley, P.M., Eds.; Cambridge University Press: Cambridge, UK; New York, NY, USA, 2013

4. Hájek, M.; Zimmermannová, J.; Helman, K.; Rozenský, L. Analysis of carbon tax efficiency in energy industries of selected EU countries. Energy Policy 2019, 134, 110955. [CrossRef]

5. Kolstad, C.D. Environmental Economics, 2nd ed.; Oxford University Press: New York, NY, USA, 2011.

6. Buchs, M.; Schnepf, S.V. Who emits most? Associations between socio-economic factors and UK households' home energy, transport, indirect and total $\mathrm{CO}_{2}$ emissions. Ecol. Econ. 2013, 90, 114-123. [CrossRef]

7. Samuelson, P.A.; Nordhaus, W.D. Economics, 19th ed.; McGraw-Hill: New York, NY, USA, 2010.

8. European Commission. Environmental Taxes-A Statistical Guide; Publications Office of the European Union: Luxembourg, 2013. [CrossRef]

9. Saleem, A.; Sági, J.; Setiawan, B. Islamic Financial Depth, Financial Intermediation, and Sustainable Economic Growth: ARDL Approach. Economies 2021, 9, 49. [CrossRef]

10. Padilla-Zea, N.; Aceto, S.; Burgos, D. Social Seducement: Empowering Social Economy Entrepreneurship. The Training Approach. Int. J. Interact. Multimed. Artif. Intell. 2019, 5, 135. [CrossRef]

11. Ronzon, T.; Piotrowski, S.; M'Barek, R.; Carus, M. A systematic approach to understanding and quantifying the EU's bioeconomy. Bio-Based Appl. Econ. 2017, 6, 1-17. [CrossRef] 
12. Comm/dg/unit. A European Green Deal. Available online: https://ec.europa.eu/info/strategy/priorities-2019-2024/europeangreen-deal_en (accessed on 7 December 2020).

13. Fornefeld, M.; Boele-Keimer, G.; Gasper, M. Chancen für Geschäftsmodelle Deutscher Unternehmen im Europäischen und Globalen Geoinformationsmarkt; Micus Management Consulting GmbH: Düsseldorf, Germany, 2008.

14. Peet, R.; Clark, G.L.; Feldman, M.P.; Gertler, M.S. The Oxford Handbook of Economic Geography. Econ. Geogr. 2002, 78, 387. [CrossRef]

15. Haining, R.P. Spatial Data Analysis: Theory and Practice; Cambridge University Press: Cambridge, UK, 2003.

16. Caha, J.; Burian, J. Comparison of Fuzzy AHP Algorithms for Land Suitability Assessment. In Cartography from Pole to Pole; Gabler: Dresden, Germany, 2017; pp. 31-46.

17. Meixnerová, L.; Menšík, M.; Pászto, V. Economic analysis and spatial arrangements of engineering SMEs performance in Olomouc region of Czech Republic. J. Int. Stud. 2017, 10, 135-145. [CrossRef]

18. Paszto, V.; Burian, J.; Panek, J.; Macku, K. Mapping the economic data-Case studies and best practices. In Proceedings of the International Multidisciplinary Scientific GeoConference Surveying Geology and Mining Ecology Management, SGEM, Albena, Bulgaria, 29 June-5 July 2017; pp. 975-982.

19. Dordmond, G.; De Oliveira, H.C.; Silva, I.R.; Swart, J. The complexity of green job creation: An analysis of green job development in Brazil. Environ. Dev. Sustain. 2021, 23, 723-746. [CrossRef]

20. Babugura, A.A. Gender and green jobs in agriculture. Agenda 2020, 34, 108-116. [CrossRef]

21. Juergens, C. Digital Data Literacy in an Economic World: Geo-Spatial Data Literacy Aspects. ISPRS Int. J. Geo-Inf. 2020, 9, 373. [CrossRef]

22. Avdeev, S. International collaboration in higher education research: A gravity model approach. Science 2021, 126, 1-20. [CrossRef]

23. Bidyuk, N.M.; Tserklevych, V.S.; Tretko, V.V. The virtual museum space as a platform for student research activities in the history of economics. Inf. Technol. Learn. Tools 2021, 81, 167-179. [CrossRef]

24. Van De Lindt, J.W.; Peacock, W.G.; Mitrani-Reiser, J.; Rosenheim, N.; Deniz, D.; Dillard, M.; Tomiczek, T.; Koliou, M.; Graettinger, A.; Crawford, P.S.; et al. Community Resilience-Focused Technical Investigation of the 2016 Lumberton, North Carolina, Flood: An Interdisciplinary Approach. Nat. Hazards Rev. 2020, 21, 04020029. [CrossRef]

25. Duarte, A.J.; Malheiro, B.; Arno, E.; Perat, I.; Silva, M.F.; Fuentes-Dura, P.; Guedes, P.; Ferreira, P. Engineering Education for Sustainable Development: The European Project Semester Approach. IEEE Trans. Educ. 2019, 63, 1-10. [CrossRef]

26. Vanchukhina, L.; Leybert, T.; Rogacheva, A.; Rudneva, Y.; Khalikova, E. New model of managerial education in technical university. Int. J. Educ. Manag. 2019, 33, 511-524. [CrossRef]

27. Leger, A.S. A Multidisciplinary Undergraduate Alternative Energy Engineering Course. IEEE Trans. Educ. 2018, 62, 34-39. [CrossRef]

28. Iglesia-Villasol, M. Aprendizaje Basado en un Proyecto Docente: Aprendizaje, creatividad, innovación y nuevos roles en la formación de profesorado en la era digital. Rev. Complut. Educ. 2018, 29, 1253-1278. [CrossRef]

29. O'Donnell, N.; Kappen, D.L.; Fitz-Walter, Z.; Deterding, S.; Nacke, L.E.; Johnson, D. How Multidisciplinary is Gamification Research? In Proceedings of the Extended Abstracts Publication of the Annual Symposium on Computer-Human Interaction in Play, Amsterdam, The Netherlands, 15-18 October 2017; ACM Press: New York, NY, USA, 2017; pp. 445-452.

30. De Jong, A.J.; Van Joolingen, W.R. Scientific Discovery Learning with Computer Simulations of Conceptual Domains. Rev. Educ. Res. 1998, 68, 179-201. [CrossRef]

31. Rieber, L.P.; Tzeng, S.-C.; Tribble, K. Discovery learning, representation, and explanation within a computer-based simulation: Finding the right mix. Learn. Instr. 2004, 14, 307-323. [CrossRef]

32. Spationomy. 2020. Available online: https://spationomy.mvso.cz/index2.php/ (accessed on 26 September 2021).

33. Jürgens, C.; Moos, N.; Redecker, A. Spationomy—Spatial Exploration of Economic Data—an Interdisciplinary Geomatics Project. KN-J. Cartogr. Geogr. Inf. 2018, 68, 66-71. [CrossRef]

34. Moos, N.; Juergens, C.; Redecker, A.P. SPATIONOMY - Spatial Exploration of Economic Data. In Proceedings of the Geosystems User Group Meeting, Germering, Germany, 6 November 2019.

35. Pászto, V.; Pánek, J. SPATIONOMY Simulation Game. In SPATIONOMY: Spatial Exploration of Economic Data and Methods of Interdisciplinary Analytics; Jürgens, C., Tominc, P., Burian, J., Eds.; Springer: Berlin/Heidelberg, Germany, 2020; pp. $305-325$.

36. Pászto, V.; Pánek, J.; Glas, R.; van Vught, J. Spationomy Simulation Game-Playful Learning in Spatial Economy Higher Education. ISPRS Int. J. Geo-Inf. 2021, 10, 74. [CrossRef]

37. Ahlqvist, O.; Schlieder, C. (Eds.) Geogames and Geoplay_Game-Based Approaches to the Analysis of Geo-Information; Springer: Berlin/Heidelberg, Germany, 2018.

38. Zabukovšek, S.S.; Tominc, P.; Bobek, S.; Štrukelj, T. Spatial Exploration of Economic Data—Insight into Attitudes of Students Towards Interdisciplinary Knowledge. ISPRS Int. J. Geo-Inf. 2020, 9, 421. [CrossRef]

39. Davis, F.D. Perceived usefulness, perceived ease of use, and user acceptance of information technology. MIS Q. 1989, 13, 319-340. [CrossRef]

40. Davis, F.D.; Bagozzi, R.P.; Warshaw, P.R. User acceptance of computer technology: A comparison of two theoretical models. Manag. Sci. 1989, 35, 982-1003. [CrossRef] 
41. Lopes, A.P.; Soler, M.; Caña, R.; Cortés, L.; Bentabol, M.; Bentabol, A.; Muñoz, M.D.M.; Esteban, A.; Luna, M. Gamification in education and active methodologies at higher education. In Proceedings of the EDULEARN19, Palma, Spain, 1-3 July 2019; Volume 1, pp. 1633-1640.

42. Chulkov, D.; Wang, X. The Educational Value of Simulation as a Teaching Strategy in a Finance Course. J. Bus. Educ. Scholarsh. Teach. 2020, 14, 40-56.

43. Bellotti, F.; Kapralos, B.; Lee, K.; Moreno-Ger, P.; Berta, R. Assessment in and of Serious Games: An Overview. Adv. Hum.-Comput. Interact. 2013, 2013, 1-11. [CrossRef]

44. Anselin, L. Spatial Econometrics: Methods and Models; Kluwer Academic Publishers: Boston, MA, USA, 1988.

45. Henttonen, K.; Johanson, J.-E.; Janhonen, M. Work-team bonding and bridging social networks, team identity and performance effectiveness. Pers. Rev. 2014, 43, 330-349. [CrossRef]

46. Fujita, M.; Krugman, P.R.; Venables, A.J. The Spatial Economy: Cities, Regions, and International Trade; MIT Press: Cambridge, MA, USA, 1999.

47. Bernanke, B.S.; Frank, R. Principles of Macroeconomics, 4th ed.; McGraw-Hill Higher Education: New York, NY, USA, 2008.

48. Zimmermannova, J. Methods in Microeconomic and Macroeconomic Issues. In SPATIONOMY: Spatial Exploration of Economic Data and Methods of Interdisciplinary Analytics; Pászto, V., Jürgens, C., Tominc, P., Burian, J., Eds.; Springer: Berlin/Heidelberg, Germany, 2020; pp. 119-148.

49. Tominc, P.; Paszto, V.; Bobek, S.; Zabukovšek, S.S. Integration and use of the interdisciplinary knowledge in the field of spatial and economics/business sciences. Croat. J. Educ.-Hrvat. Časopis Odgoj Obraz. 2019, 21, 861-892. [CrossRef]

50. SPATIONOMY 2.0. 2021. Available online: https://SPATIONOMY.mvso.cz/2.0/ (accessed on 19 August 2021). 